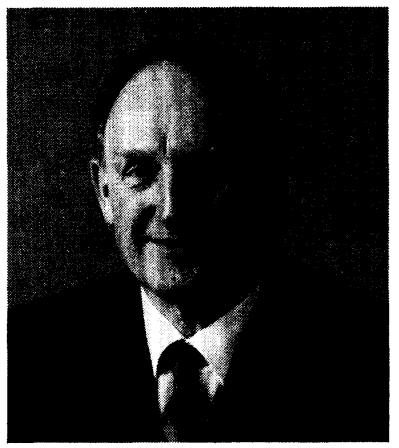

\section{Welcome to Volume 33}

As we launch the new year of 1994 , we look forward to another important year for your journal Optical Engineering, which will continue to report on "research and development in optical science and engineering." On behalf of the entire editorial staff in Rochester and Bellingham, I bring you greetings for the new year.

\section{Goodbye, Joe; Hello, Jim!}

We start the new year with a new executive director in place and already running at full speed. We all look forward to working with Jim Pearson to further the mission of SPIEThe International Society for Optical Engineering. From this editorial page may we say "welcome aboard." Dr. James E. Pearson is already well known to many of us because he has been, and is, a major contributor to our field of optical science and engineering. His B.S. and M.S. degrees in electrical engineering and his Ph.D. in electrical engineering and physics, all from the California Institute of Technology, provided an excellent background for a successful career as scientist, leader, administrator, business manager, and organization builder. His experiences at Los Alamos National Laboratory, Hughes Research Laboratories, and United Technologies speak for themselves. His most recent positions as president and general manager of United Technologies Optical Systems (UTOS) from 1986-93, and as chief scientist/director of Core Competency at United Technologies Research Center from 1991-93 provided the capstone to his on-the-job experience while he has been "in-training" for the executive director's position. I am sure that Jim is glad that his lengthy apprenticeship is over! Now to the real work!

Jim takes over a Society that has been very successfully managed by Joe Yaver and his team. Joe retires from the

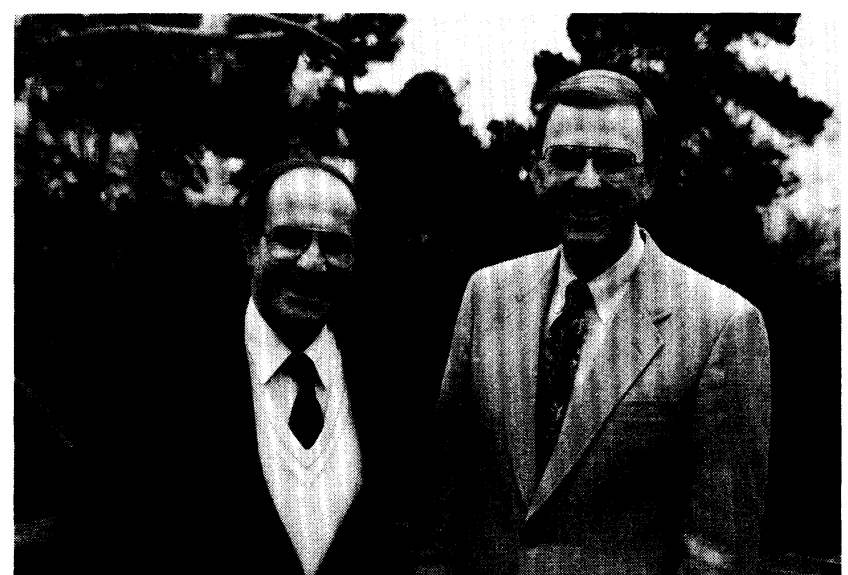

Joe Yaver (left), retiring SPIE executive director, and

Jim Pearson (right), the new executive director.

position of executive director with a tremendous record of dedicated service. The growth and status of the Society have been unprecedented. It has been my personal privilege to have been associated with the Society through the whole of Joe's tenure and to have worked with him on many projects both in official capacities as director, president, and editor, but perhaps more importantly as a member. Joe had the great gift of vision for the Society and its programs and the ability to work with staff and members alike to move the Society forward to mutually determined goals. Joseph Yaver, we owe you an enormous debt of gratitude for which a simple "thank you" is not sufficient-but maybe its simplicity makes it the most meaningful tribute. Thank you.

Brian J. Thompson Editor 
February 1994

Magnetospheric Imagery and Atmospheric Remote Sensing, Part 2

Supriya Chakrabarti

Boston University

Center for Space Physics

725 Commonwealth Avenue

Boston, MA 02215

E-mail: supc@bu-ast.bu.edu

617/353-5990 • 617/353-6463 FAX

\section{March 1994}

Infrared Technology, Part 2

Marija S. Scholl

Alenka Associates

P.O. Box 27408

Tempe, AZ 85285-7408

E-mail: msscholl@aol.com

602/491-7814

\section{May 1994}

Semiconductor Infrared Detectors

Antoni Rogalski

Military Technical Academy

Institute of Technical Physics

Kaliskiego St. 25

01-489 Warsaw 49, Poland

$4822369109 \cdot 4822362254$ FAX

Optical Interconnects and Packaging

Sing Lee

University of California/San Diego

E\&CE Department

La Jolla, CA 92093-0407

619/534-2413 • 619/534-1225 FAX

June 1994

Optical Science \& Engineering in India

Rajpal S. Sirohi

Indian Institute of Technology

Applied Optics Laboratory

Physics Department

Madras-600 036, India

044-2351365 ext. $221 \cdot 044-2350509$ FAX

Optical Pattern Recognition

Joseph L. Horner

Rome Laboratory

EROP

Hanscom AFB, MA 01731-5000

$617 / 377-3841 \cdot 617 / 377-5041$ FAX

Bahram Javidi

University of Connecticut

School of Engineering

Department of Electrical and Systems Engineering

Room 312, U-157

260 Glenbrook Road

Storrs, CT 06269-3157

203/486-4816 • 203/486-3789 FAX

July 1994

Adaptive Wavelet Transforms

Harold H. Szu

U.S. Navy

Naval Surface Warfare Center

Code R44

10901 New Hampshire Avenue

Silver Springs, MD 20903-5000

301/394-3097 • 301/394-3923 FAX
August 1994

Digital Image Recovery and Synthesis

Paul S. Idell

Rockwell International

Rocketdyne Division

MS SS46

P.O. Box 7922

Canoga Park, CA 91309-7922

$818 / 586-8238 \bullet 818 / 586-5295$ FAX

E-mail: pidell@windance.rdyne.rockwell.com

\section{September 1994}

Optics in South Africa

Hannes Markusse

ELOPTRO

Institute of Atomic Physics

P.O. Box 869

Kempton Park 1620, South Africa

Maurice W. McDowell

CSIR/Production Technology Div.

Productiontek

P.O. Box 395

Pretoria 0001, South Africa

$27128413418 \cdot 27128412131$ FAX

\section{October 1994}

Optics in Russia

V. Ya. Panchenko

Scientific Research Center for Technological Lasers

Russia Academy of Sciences

B-333, Gubkina, 3

117971 Moscow, Russia

E-mail: ilc@compnet.npimsu.msk.su (095)135-54-30 • (095)334-02-01 FAX

Manuscripts due March 1, 1994.

\section{November 1994}

\section{Micro-Optics}

Chandrasekhar Roychoudhuri

University of Connecticut at Storrs

Photonics Research Center

MS-157, Room 312

260 Glenbrook Road

Storrs, CT 06269-3157

203/486-4816 • 203/486-3789 FAX

Manuscripts due April 1, 1994.

\section{December 1994}

Optics in Ireland

John Hegarty

C. D. Hussey

University of Dublin

Trinity College

Department of Pure and Applied Physics

Dublin 2, Ireland

+353-1-7022019 • +353-1-711759 FAX

Manuscripts due May 1, 1994.

\section{January 1995}

X-Ray/EUV Optics

Richard B. Hoover

NASA Marshall Space Flight Center

ES52 Space Science Center

Huntsville, AL 35812-0001

E-mail: hoover@ssl.msfc.nasa.gov

205/544-7617 • 205/544-5856 FAX

Manuscripts due June 1, 1994.
February 1995

High Heat Flux Optical Engineering

Ali M. Khounsary

Argonne National Laboratory

Advanced Photon Source, APS 362

Argonne, IL 60439

708/252-3384 • 708/252-3222 FAX

Manuscripts due July 1, 1994.

March 1995

Optical Engineering in Ophthalmology

Suganda Jutamulia

Kowa Company, Ltd.

Silicon Valley Office

100 Homeland Court, Suite 302

San Jose, CA 95112

408/441-9300 • 408/441-0537 FAX

Toshimitsu Asakura

Hokkaido University

Research Institute for Electronic Science

Sapporo, 060 Japan

81-11-716-2111 • 81-11-758-3173 FAX

Manuscripts due Aug. 1, 1994.

\section{April 1995}

Optics in the Ukraine

Oleg V. Angelsky

Chernovtsy University

Department of Correlation Optics

2 Kosyubinsky Street

274012 Chernovtsy

Ukraine

(03722) 44730 • (03722) 41314 FAX

Manuscripts due Aug. 15, 1994

July 1995

Optics in Switzerland

P. K. Rastogi

Swiss Federal Institute of Technology-Lausanne

Laboratory of Stress Analysis

CH-1015 Lausanne

Switzerland

E-mail: rastogi@elgc.epfl.ch

(021) 6932445 • (021) 6934748 FAX

Manuscripts due Nov. 15, 1994

\section{September 1995}

Optical Science \& Engineering in Finland

Seppo Honkanen

Nokia Research Center

P.O. Box 156

SF-02101 Espoo

Finland

+358043761・+35804552557 FAX

Manuscripts due Jan. 15, 1995

November 1995

Optical Remote Sensing and Image

Processing

Mohammad A. Karim

Bradley D. Duncan

University of Dayton

Center for Electro-Optics

300 College Park

Dayton, OH 45469-0227

$513 / 229-2241 \cdot 513 / 229-3177$

513/229-2471 FAX

Manuscripts due April 1, 1995 